\title{
ACCESSIBLE TOURISM SERVICES IN THE NORTH GREAT PLAIN REGION
}

Authors:

\author{
András Tatár $(\mathrm{PhD} .)^{1}$ \\ Andrea Puskás Lenténé (PhD.) ${ }^{1}$ \\ Melinda Biró (PhD.) \\ József Márton Pucsok (PhD.) ${ }^{1}$ \\ Péter Hidvégi $(\mathrm{PhD} .)^{1}$ \\ ${ }^{1}$ University of Debrecen, \\ Institute of Sport Sciences \\ (Debrecen, Hungary) \\ E-mail adress of the first author: \\ tatar.andras@sport.unideb.hu
}

\section{Lectors:}

Éva Bába Bácsné (PhD.)

University of Debrecen

(Hungary)

Anetta Müller (PhD.)

University of Debrecen

(Hungary)

Tatár A., Lenténé Puskás A., Biró M., Pucsok M. J., \& Hidvégi P. (2019): Accessible tourism services in the North Great Plain region. Különleges Bánásmód, 5. (1). 77-81. DOI 10.18458/KB.2019.1.77

\begin{abstract}
In the ever-increasing competition between the tourist destinations, the rethinking of the primary and secondary attraction factors (Bácsné et. al., 2018), their re-planning, supplementation, and development are indispensable. This is also true for the Hungary and the Northern Great Plain region, where the availability of therapeutic and thermal water is a priority factor (Müller \& Könyves, 2006; Müller \& Kórik 2009; Michalkó \& Rácz 2011; Löwei 2017). The further development towards accessible tourism, even for a long-standing, well-established destination in health tourism is to be considered, in order service providers not only could strengthen their existing position but also open up to new markets and consumer groups (Mosonyi et. al. 2013, Lengyel 2015). The understanding and implementation of strategies for new consumer groups include the product and service evaluation based on individual leisure constraints.
\end{abstract}

Keywords: accessible tourism, destination attraction factors, inclusion, leisure constraints of people with special needs

Disciplines: business economics and organizational studies

\section{Absztrakt}

HOZZAFÉRHETŐ TURISZTIKAI LEHETŐSÉGEK AZ ÉSZAK-ALFÖLDI RÉGIÓBAN

$\mathrm{Az}$ idegenforgalmi célpontok közötti egyre növekvő versenyben elengedhetetlenek az elsődleges és a másodlagos vonzerôk újragondolása (Bácsné et al., 2018), újratervezése, kiegészítése és fejlesztése. Ez igaz Magyarországra és ezen belül az észak-alföldi régióra is, ahol a terápiás célra hasznosítható gyógyvíz és termálvíz rendelkezésre állása kiemelt tényező (Müller és Könyves, 2006; Müller és Kórik 2009; Michalkó és Rácz 2011; Löwei 2017). A hozzáférhető idegenforgalom irányába történő továbbfejlesztést még az egészségturizmus régóta, jól működő desztinációinak is fel kell vállalniuk, hogy ezzel a szolgáltatók ne csak megerósítsék meglévó pozíciójukat, hanem új piaci szegmensekre és fogyasztói csoportokra is nyitottak legyenek (Mosonyi et al. 2013, Lengyel 2015). Az új fogyasztói csoportok fogyasztói szokásai megértése és az ennek megfelelő stratégia megvalósítása magában foglalja az egyéni szabadidős korlátokon alapuló termék- és szolgáltatásértékelést.

Kulcsszavak: hozzáférhető idegenforgalom, rendeltetési hely vonzereje, befogadás, szabadidős korlátok a speciális igényúek számára

Diszciplínák: gazdálkodás- és szervezéstudomány 
Several studies and comprehensive surveys have been conducted on the travel products market about the accessibility of products and services. However, the findings show that while travel products and itineraries are available everywhere for the public, they are often inadequate for people with special needs. Even though people with special needs might have impairments, they also have profound travel needs and motivations. When prospective customers with special needs are provided with various alternatives, they would have stronger intentions, preferences, and perceptions, and could partake in outdoor and leisure activities (Darcy, 1998, Laoues-Müller, 2018). When studying limitations on participation and consumer attitudes the hierarchical model posits that leisure constraints exist at three levels: intrapersonal, interpersonal, and structural which must be navigated sequentially for participation to take place or continue/progress (Godbey et al., 2010).

In our recent approach, we focused on the existing features of destination management, product and service elements which are mainly related to the structural constraints, and may influence consumer behavior and choices of customers with special needs.

\section{THEORETICAL BACKGROUND}

Health tourism refers to the area of tourism where the main purpose of tourism is to improve and preserve health. Health tourism can be a form of spa or wellness tourism (Müller et. al. 2005). The main motivation of medical tourism is the improvement of the health condition, healing, rehabilitation (Müller et. al. 2018a), where the aim of the health care treatments included in the provider's offer is to use other tourism services as well (Müller et. al. 2018b). Generally, those who wish to heal are usually prescribing, but in recent years, with increasing purchasing power and widening benefits, self-financing of services is becoming increasingly important. The goal of wellness tourism is to preserve health, in which guests use tourism services that also contain health elements. Generally, wellness providers offer attractive health care prevention programs in an attractive environment (KSH 2011).

One of the most significant elements of tourism potential in the Northern Great Plain is health tourism, as the region is rich in thermal and medicinal waters. In 2011, there were 72 baths in the region - $16 \%$ of those operating in the country - 26 of them in Hajdú-Bihar and Jász-Nagykun-Szolnok counties and 20 units in Szabolcs-Szatmár-Bereg counties. Of the spas, 29 were spa baths, 26 ther- mal baths, and 17 baths. Also, there are 22 beaches, 54 swimming pools and 12 other baths in the region. Most of the spas - 15 - operated in HajdúBihar county. The largest number of thermal baths can be found in Jász-Nagykun-Szolnok county, by number 11.

In 2012, 3 of the settlements in the North Great Plain were spa hotels in 9 settlements. Among the settlements of the Northern Great Plain, which are known primarily as health tourism destinations, the most visited were Hajdúszoboszló, Berekfürdő, and Cserkeszőlő, where the total number of guest nights of all commercial accommodations was registered at 53\% (HCSO 2013).

One of the outstanding features of the North Great Plain region is the treasure of thermal and thermal water found in the area. This may be a good chance for more settlements in the region to compete in the increasingly fierce competition of destinations (Müller et al., 2005). In this competition, a new element has emerged, a range of services for people with special needs, which further illustrates physical accessibility and the range of medical services. People with special needs who are looking for accessible tourism services are also different in their motivation. According to TSAY (2010), the use of services and decisions to do so greatly help to overcome the mistrust, shyness, and lack of confidence of the individual. However, this requires a supportive environment and adequate supply. Crawford et al. (1991) proposed the leisure constraints model which classifies factors influencing individual leisure constraints into three categories: intrapersonal, interpersonal and structural. In our investigation, we focused on the analysis of the probable existence of structural constraints in the services and product environment.

The attractiveness factors of the destinations are primary (capability-type) - thermal water, natural environment, cultural environment - and secondary (built-in) - spa, spa, wellness services, related other tourism services, architectural design, cultural and sports programs, conference services, gastronomy (BOROS et al., 2012, Müller et. al. 2018b).

\section{METHODS}

The Institute of Sport Science at the University of Debrecen surveyed on the topic of tourism and wellness services in the North Great Plain region, using a structured questionnaire. Furthermore, intensive online research was conducted to touch into all available information resources regarding the targeted destinations. In this study, our conclusions were formulated for the answers and infor- 
mation gathered so far in 2017 and 2018 about a priority destination, namely Cserkeszőlő.

\section{Results}

Accessible tourism means tourism that is equally accessible to everyone. It includes people with disabilities, people with temporary disabilities, the elderly, young children and multi-generational families. Physical accessibility is essential for health tourism providers but is not yet complete in the area of related services.

Cserkeszőlő is a well-organized spa and beach in South Great Plain (but located in the region) without significant secondary attractions. The existing swimming pools are well separated from the parts for other leisure activities; there is a well planned and coordinated set up for the health and leisure related areas. The medical tourism was based on iodine-bromine water of 82 degrees Celsius. In 2010, the well-designed indoor swimming pool was completed, which made it possible to operate comfortably and smoothly throughout the year. As an example of successful smaller beaches, it was mentioned in the Great Plain, which has led to the development of accommodation and service developments.

The spa also provides medical services, so during the renovation, rebuilding, and development of the physical environment the special needs have been taken into account to a great extent, as well as providing the special equipment needed to use the pools. Naturally, the development of the spa has significantly contributed to the development of the settlement itself, which was unfortunately affected by the economic crisis that began in 2008. The population expects similar momentum from the current transport development project - i.e., building the M44 road - although its effects can be difficult to measure until the project is fully completed.

When looking at the availability and quality of accessible tourism services, we need to consider all areas of it, including hotels, hospitality, other services, tourist attractions, transport, and communication.

In our study, we focused primarily on accommodations, as well as on the services they provide. The results of the earlier research in the field of health tourism in the spa of Cserkeszóló gave us a good starting point (Müller et al., 2005). The data related to the services provided for people with special needs collected so far are much ambivalent. There is a need for further data collection and data analysis to draw definitive conclusions. However, based on the preliminary results available now, initial recommendations might be formulated right away.
Accommodation. More than 130 rooms and 16 guest houses have been built alongside the previously available campsite, and the number of private accommodation has also increased steadily. According to the characteristics of thermal water, which is the primary attraction factor, the main product is the range of health tourism services, which has brought along the physical accessibility of the accommodation. Private accommodation providers have also begun to recognize the potential of special needs, for example, the construction of a physically accessible private pension, as well as accessible facilities for the yurt camp next to the spa. However, it can be stated that the destination has only taken the initial step, as the development potential is not fully exploited in terms of secondary attractiveness.

Hospitality. The hospitality-related hospitality has the same characteristics as the hotels themselves, as they were developed along with the accommodation or in parallel. However, the development opportunities mentioned earlier are more prominent here, as, in addition to the physical environment, human interaction is becoming increasingly important. The question of staff training and sensitization, which we have not yet received a satisfactory answer for the destination, is already here.

Other services. We do not have comprehensive data for other services. We have no data about the settlement as defined by the law, especially about physical aspects, accessibility, but the full availability of services. From the information provided by the hotels, we can only conclude - knowing the current labor market trends - that the lack of specially trained, a trained workforce with them is present in other service areas.

Tourist attraction. Cserkeszőlő itself has no outstanding tourist attractions; the destination concept is built around the spa. In the opinion of others, this is not sustainable in the long term, from retaining and re-appearance of the guests by experience. The settlement is one of the youngest settlements in the county since 1 January 1952, as it was formerly part of Tiszakürt. The main reason for the separation was discovered in the hydrocarbon exploration of the Hungarian-American Oil Research Company in 1942-43. Taking advantage of the limited possibilities of the settlement, it tries to develop the offer of a tourist attraction. However, the elements of accessible tourism development have not been exhausted to its full extent so far. Among the limited possibilities are the renovated wine house and cellar and the Szinyei Merse Castle, the Cserkeszóló Kunhalom, and the natural values of the so-called Great Forest and the Great Ferto Lake from its wildlife. Regarding availability and 
accessibility, each of them is waiting for serious improvement.

However, the location of Cserkeszőló, the fact that he was part of Tiszakürt earlier, has great potential. One of the most beautiful arboretum in Hungary is located in Tiszakürt. The "brother" of the arboretum of Tiszakürt is located in Szarvas, a situation - i.e., proximity to two significant natural values - a great attraction for nature lovers. We could talk about similar opportunities in the nearby Tisza and Körös, but their development has not been done so far in a way and to the extent that they can be considered from accessible tourism.

Transport. It is located in the southern part of Jász-Nagykun-Szolnok county, in the Tiszazug, between Tisza and Hármas-Körös. In the west, the nearest cities are Kecskemét, Tiszaföldvár to the north, Kunszentmárton to the east. The main road 44 passes through the village, while the Kecskemét - Kunszentmárton railway line does not touch, but in the south, it passes Cserkeszőlő towards Csépa and Szelevény. It is $127 \mathrm{~km}$ from Budapest, $45 \mathrm{~km}$ from Szolnok and Kecskemét. Due to its location, its approach by car is most obvious, which is especially important for people with special needs, as the available public transport options - longdistance bus services - are not fully accessible. The M44 development mentioned earlier does not provide any information as to the extent to which the current situation or the accessibility of the settlement will change or improve. Based on the travel habits of people with special needs, according to which car traffic and special bus services are used in groups, it is hoped that the attraction of destination will be increased regarding accessibility.

Communication. The development potential of the destination is the most significant in the field of communication. From the information we received in our questionnaire, "Is the service provider's news about the product and service available to guests with special needs listed above?" The most prominent is the spa, which is the main attraction of the destination, where the website is also not accessible.

\section{Discussion}

When examining Cserkeszőlő as a major health tourism destination, we find a surprising result when we consider the barrier-free tourism services. Based on the time since the construction of the spa in 1955, we can think that the health tourism service, the characteristics, and needs of those who use it the most, is a barrier to services, or at least the service providers strive to do so.

If we assume that a service location within barrier-free accessibility allows all products and services, it offers to be equally accessible to everyone, including people with disabilities, the elderly, and any other user with special needs/needs, we can rightly think of the existence of overlaps between the needs of the target groups.

Regarding increasing competition among the destinations, it is also important that Cserkeszőlö and the providers of tourist services there review the services they provide and the attractiveness factors to ensure their maintenance by opening them up for the development of accessible tourism. Building on the existing basic accessibility, which is most evident in the development of the physical environment, it also allows for the involvement of new consumer groups and the general quality of services.

The publication was supported by EFOP-3.6.216-2017-00003. The project was funded by the European Union and co-financed by the European Social Fund.

\section{REFERENCES}

Bácsné, B. É., Müller, A., Molnár, A., Dobay, B., Bács, Z., \& Petô, K. (2018): TourismVolunteering And Sport - Connections And Implications From A Research. Acta Oeconomica Universitatis Selye, 7 (2). 19-33.,

Boros, Sz., Mondok, A., \& Várhelyi, T. (2012). Az. egészégturizmus szolgáltatásai és menedzsmentje. Szolnoki Főiskola, Szolnok.

Crawford, D.W., Jackson, E.L., \& Godbey, G. (1991). A Hierarchical model of leisure constraints. Leisure Science 13(4). 309-320.

Darcy, S. (1998). Anxiety to Access: The Tourism Patterns and Experiences of New South Wales People with a physical disability. Tourism New South Wales, Sydney. Australia.

Godbey, G., Crawford, D.W., \& Shen, X.S. (2010). Assessing Hierarchical Leisure Constraints Theory after Two Decades. Journal of Leisure Research, 42. (1). 111-134

Hajdúszoboszló és az egészségturizmus - KSH 2011. március. Idegenforgalmi tendenciák, sajátosságok Észak-Alföld megyéiben - KSH 2013. május

Könyves, E., Müller, A., Szalay, F., Szabó, R (2005): Cserkeszőlő és Karcag egészségturizmusának összehasonlító elemzése. Szolnoki Tudományos Közlemények 9. Paper: 9.

Laoues, C. N., \& Müller, A., (2018): Az integrációszegregáció helyzete egy kutatás tükrében. Különleges Bánásmód, 4. (4). 19-31. 
Lengyel, A. (2015): Magyarország egészségturisztikai desztinációként való márkázása: aszinkronitási problémák. Economica, 8.(1). 68-73.

Lövei K. K. (2017): A Fürdők Jelentősége az Észak-Alföldi Régió Egészségturizmusának Fejlesztésében, Köztes-Európa. Társadalomtudományi folyóirat A Virtuális Intézet KözépEurópa Kutatására Közleményei, 9. (1-2.) 21-22., 205-214.

Michalkó G., \& Rácz T. (2011): Egészségturiz̧uus és életminöség Magyarországon: fejezetek az egészség, az utazás és a jól (l)ét magyarországi összefuiggéseiról. Budapest, MTA. Földrajztudományi Kutatóintézet.

Mosonyi, A., Lengyel, A., \& Müller, A. (2013): Branding potential of spas in the Northern Plain and the Mid-Transdanubian Regions. Abstract - Applied Studies. Agribusiness And Commerce 7. (4-5). 97-101.

Müller, A., \& Könyves, E (2006): Az egészségturizmus lehetőségei az Észak-alföldi régióban. $A c$ ta Academiae Paedagogicae Agriensis Nova Series: Sectio Sport, 33. 132-143.

Müller, A., \& Kórik, V. (2009): Az észak-alföldi fürdők szerepe a turizmusban és a rekreációban. Economica (Szolnok) 2. 58-72.

Müller, A., Könyves, E., \& Szabó, R. (2005): A wellnessturizmus sokszínú kínálatának bemutatása. Iskolai Testnevelés És Sport - Elméleti Módszertani És Információs Szaklap 27. pp. 29-34.

Müller, A., Pfau, C., Gabnai, Z. Bácsné, B. É., Borbély, A., \& Petó, K. (2018b): A gyógy-, wellness- és sportszolgáltatások fejlesztési lehetőségei a gyógyturizmusban egy hazai kutatás tükrében. International Journal Of Engineering And Management Sciences/Müszaki És Menedzsment Tudományi Közlemények, 3 (4). 101-114.

Müller, A., Ráthonyi, G., Bíró, M., Ráthonyi, Ó. K., Bács, Z., Ács, P., Hegyi. G., \& Bácsné, B. É. (2018a): The effect of complex climate therapy on rehabilitation results of elderly asthmatic and chronic obstructive airways disease (COPD) patients. European Journal Of Integrative Medicine 20. 106-114.

Tsai, C.Y. (2010): The physical disabilities' travel behaviors. African Journal of Business Management 4.(4). 512-525. 